\title{
Stereochemistry of Coordination Compounds. From Alfred Werner to the 21st Century
}

\author{
Alex von Zelewsky
}

\begin{abstract}
As a contribution to the scientific symposium, November 22nd, 2013, commemorating the Nobel Prize awarded to Alfred Werner in 1913, a presentation of the development of stereochemistry of coordination compounds during the past 120 years was given. Stereochemistry was fundamental to Werner's theory of coordination compounds. After Werner's death in 1919, stereochemistry in this field did not progress much further for almost 20 years, but then developed continuously. It was realized that stereochemical features of elements showing coordination numbers larger than four are responsible for an almost unlimited number of stereochemical possibilities, thus opening a molecular world of new structures. In the beginning of the 21st century, interest in the field rose again considerably, mainly due to the potential of stereoselective catalysis, and the self-assembly of supramolecular structures. An end of these developments is not in sight. Here an abbreviated version of the lecture is given. A PowerPoint ${ }^{\circledR}$ file, or a video of the presentation, can be downloaded. ${ }^{[1,2]}$
\end{abstract}

Keywords: Chirality · Coordination compounds · Stereochemistry $\cdot$ Stereoselectivity $\cdot$ Werner, Alfred

\section{Introduction}

20 years after the publication of his fundamental formulation of the coordination concept, Alfred Werner was awarded the Nobel Prize in Chemistry in 1913. Werner's views of the molecular structure of compounds of metallic elements proved to be correct for a vast number of compounds and it is still the basis for contemporary research and development in many branches of chemistry. Werner based his theory to a large part on considerations about the numbers and types of isomers of compounds of transition metals. It is basically a theory exploring the various possibilities to arrange atoms in three-dimensional space and this is nothing else but the subject of stereochemistry.

The coordination theory is one of the unbreakable hard rocks of science that will

\footnotetext{
${ }^{*}$ Correspondence: Prof. Dr. A. von Zelewsky Prof. emerit. University of Fribourg Noveledo 58

$\mathrm{CH}-6614$ Brissago

Tel. +41793501570

E-mail: alexander.vonzelewsky@unifr.ch

www: http://vonzelewsky.ch/Brissago_AVZ/

Personlich_Brissago.html
}

probably never be succeeded by a better concept. To commemorate the centenary of the Nobel Prize of Alfred Werner, the Department of Chemistry at the University of Zürich organized a symposium on several aspects of coordination chemistry. I had the privilege to review the development of stereochemistry of coordination compounds from Alfred Werner to the present. Here, only a short excerpt of the presentation in the symposium is given. A first specialized textbook on 'Stereochemistry of Coordination Compounds' [3] by the present author appeared one hundred years after the basic publication by Alfred Werner. ${ }^{[4]}$ It is fully referenced and covers also the historical development in some detail. A second, more specialized book by Amouri and Gruselle, was published recently. ${ }^{[5]}$ It covers the topical subject of chirality in transition metal chemistry in great detail. Chirality was already of central interest to Alfred Werner. His experimental proof in metal compounds was the main reason for the Nobel committee to award the Prize in 1913. In addition to these two books, a number of reviews have been published in recent years, ${ }^{[6-10]}$ proving the revived interest in the subject.

\section{The Development of Stereochemistry of Coordination Compounds since Alfred Werner}

After the proposition of the tetrahedral carbon atom by vant'Hoff and Le Bel in 1874, stereochemistry of organic com- pounds developed rapidly during the last quarter of the 19th century, as recognized by the second Nobel Prize in Chemistry awarded to Emil Fischer in 1902. In the beginning of this period, inorganic chemistry was still dominated by the view of the Danish chemist Sophus Mats Jørgensen, who was an excellent experimental chemist. Jørgensen adhered strictly to the chain theory of Blomstrand, one of the leading chemists of the 19th century. The seminal publication of a 27-year-old chemist, Alfred Werner, appeared in 1893. ${ }^{[4]}$ Werner introduced the octahedron as a coordination center. Most notably, in the same publication, he attributed to $\mathrm{Pt}(\mathrm{II})$ compounds the coordination number four in a square planar arrangement. The tetrahedral arrangement for coordination number four, however, was so deeply burned into the mind of chemists during the last quarter of the 19th century that it needed a highly independent mind to dare to propose the planar structure for metal compounds. In 1899 the first mention of the possibility of 'asymmetry' in an octahedral complex followed ${ }^{[11]}$ and in 1911 the proof of the existence of two separable enantiomers in a cobalt compound was presented. ${ }^{[12]}$ It was shown in 1914, finally, that optical activity is not necessarily associated with the presence of carbon. ${ }^{[13]}$ A carbon-free complex, Co(hexol), comprising a central cobalt atom, surrounded by four bidentate ligands that are themselves cobalt-amine complexes, was separated into its enantiomers. After 1914, the activity of the Zurich group ceased rapidly, due to Werner's severe ill- 
ness. One remarkable paper appeared in Helvetica Chimica Acta in 1920 authored by Smirnoff, one of the last assistants of Werner. ${ }^{[14]}$ This is the first publication of a system, where preferred chirality@metal is induced by a chiral organic ligand. This system has been recently reexamined with modern analytical methods, especially multinuclear high-resolution NMR spectroscopy. ${ }^{[15]}$ Smirnoff's results could be confirmed and more detailed information about the stereochemical course of the formation of this coordination compound was obtained. Although Smirnoff's publication was a first in stereoselective synthesis of coordination compounds, it went unnoticed for more than 20 years. It was cited a few times (slide 20 ${ }^{[1]}$ ) in the period after 1945 until 1980 by the Australian school of Dwyer and Sargeson. ${ }^{[16,17]}$ But after 1994, the number of citations of this classical publication has risen steadily again.

As already mentioned, the development of stereochemistry of coordination compounds stagnated for a period of more than 20 years after Werner's death. Interest in this subject was revived by the American school, founded by John C. Bailar Jr. (1904-1991). Bailar published a 37-part series 'The Stereochemistry of Complex Compounds' from 1934-1985. Therein the original Werner concept was extended and systematized profoundly. A large number of experimental observations proved again and again the correctness of Werner's original ideas about the spatial arrangements of atoms in coordination compounds. Bailar was awarded the Werner Gold Medal by the Swiss Chemical Society in 1966, the 100th anniversary of the birth of Alfred Werner. ${ }^{[18]}$ From about 1990 on, the interest in stereochemistry of coordination compounds rose again, nourished by the development of supramolecular chemistry, where stereochemical aspects are often crucial. An interesting application is the synthesis of topological isomers of molecules using metallic elements as coordination cen- ters. A racemic trefoil knot, which represents a topologically chiral structure, was synthesized by the group of Sauvage. ${ }^{[19]}$ Using chiragen-type ligands ${ }^{[20]}$ a completely stereoselective synthesis of one enantiomer of a trefoil knot in pure form could be achieved. ${ }^{[21]}$ These developments have been recently discussed in a timely review.[22]

A new era, that of asymmetric catalysis, has developed in the last quarter of the 20th century. In most cases stereoselective catalysts are based on transition metal complexes carrying organic ligands having themselves stereogenic centers. The field was reviewed by Ernst Peter Kündig of Geneva University in this symposium and presented in this issue. ${ }^{[23]}$ Knowles, Noyori and Sharpless shared the Nobel Prize 2001 "for their work on chirally catalyzed hydrogenation and oxidation reactions". Applications of these reaction, leading often to enantiomerically almost pure chiral compounds have become extremely important for the preparation of fine chemicals, often used as starting materials for pharmaceutical products. Enantiomeric purity is nowadays required for all asymmetric molecules used in pharmaceutical products. New promising developments, where coordination compounds that are chiral@ metal are used for catalytic purposes have been proposed.[24]

\section{Acknowledgments}

The author commemorates his former teachers at the ETHZ in the 1950th, notably Gerold Schwarzenbach, who provided an excellent introduction into general coordination chemistry and Vladimir Prelog, who seeded the virus of chirality in an efficient way. I thank with deep gratitude all my 54 graduate students in Fribourg (slide 32 of ref. [1]) and several dozens of post docs. Without them our contribution to coordination chemistry would not have been possible. Cooperation on an international level was also very important. I want to mention the groups of Vincenzo Balzani of Bologna University, Fritz Vögtle of the University of
Bonn and J.-P. Sauvage of Strasbourg. Several others contributed also in an important way. All together, I have never regretted to have dedicated my life as a researcher to coordination chemistry, founded by Alfred Werner 120 years ago, and still flourishing abundantly.

Received: March 10, 2014

[1] https://www.dropbox.com/s/y3nplidaz8befmm/ Werner_13_UNIZH.ppt

[2] http://www.youtube.com/watch? $v=Z 0 q_{-}$ gGfyy $8 \mathrm{c}$

[3] A. von Zelewsky, 'Stereochemistry of Coordination Compounds', Wiley, Chichester, 1996, ISBN 978-0471955993.

[4] A. Werner, Z. Anorg. Chem. 1893, 3, 267.

[5] H. Amouri, M. Gruselle, 'Chirality in Transition Metal Chemistry', Wiley, Chichester, 2008, ISBN 978-0470060544.

[6] E. C. Constable, Chem. Soc. Rev. 2013, 42, 1637.

[7] L. H. Gade, Chemie in unserer Zeit 2002, 36, 175.

[8] E. Meggers, Eur. J. Inorg. Chem. 2011, 2911.

[9] U. Knof, A. von Zelewsky, Angew. Chem. Int. Ed. 1999, 38, 302.

[10] A. von Zelewsky, O. Mamula, J. Chem. Soc., Dalton Trans. 2000, 219.

[11] A. Vilmos, A. Werner, Z. Anorg. Allg. Chem. 1899, $21,145$.

[12] A. Werner, Ber. Dtsch. Chem. Ges. 1911, 44, 1887.

[13] A. Werner, Ber. Dtsch. Chem. Ges. 1914, 47, 3087.

[14] A. Smirnoff, Helv. Chim. Acta 1920, 3, 177.

[15] D. Drahonovsky, A. von Zelewsky, Helv. Chim. Acta 2005, 88, 496.

[16] F. P. Dwyer, F. L. Garvan, A. Shulman, J. Am. Chem. Soc. 1959, 81, 290.

[17] D. A. Buckingham, L. G. Marzilli, A. M. Sargeson. J. Am. Chem. Soc. 1969, 91, 5227.

[18] J. C. Bailar, Helv. Chim. Acta 'Fasciculus extraordinarius Alfred Werner', 1967, 82-92.

[19] G. Rapenne, C. Dietrich-Buchecker, J.-P. Sauvage, J. Am. Chem. Soc. 1996, 118, 10932.

[20] P. Hayoz, A. Von Zelewsky, Tetrahedron Lett. 1992, 33, 5165

[21] L.-E. Perret-Aebi, A. Von Zelewsky, C. Dietrich-Buchecker, J.-P. Sauvage, Angew. Chem. Int. Ed. 2004, 43, 4482.

[22] J. F. Ayme, J. E. Beves, C. J. Campbell, D. A. Leigh, Chem. Soc. Rev. 2013, 42, 1700.

[23] E. P. Kündig, Chimia 2014, 68, 312.

[24] L.-A. Chen, W. Xu, B. Huang, J. Ma, L. Wang, J. Xi, K. Harms, L. Gong, E. Meggers, J. Am. Chem. Soc. 2013, 135, 10598 